\title{
Harpacticoida (Crustacea: Copepoda) associated with cold-water coral substrates in the Porcupine Seabight (NE Atlantic): species composition, diversity and reflections on the origin of the fauna
}

\author{
HENDRIK GHEERARDYN, MARLEEN DE TROCH, MAGDA VINCX \\ and ANN VANREUSEL \\ Marine Biology Section, Biology Department, Ghent University, Campus Sterre, Building S8, Krijgslaan 281, \\ B-9000 Ghent, Belgium. E-mail: hendrik.gheerardyn@ugent.be
}

\begin{abstract}
SUMMARY: The harpacticoid copepod fauna associated with the coral degradation zone of Lophelia pertusa (Linnaeus, 1758) reefs was investigated for the first time in the Porcupine Seabight (NE Atlantic). The species list of the coral degradation zone includes 157 species, 62 genera and 19 families, and the most species-rich families were Ectinosomatidae (36 species), Ameiridae (29 species) and Argestidae (17 species). At least $80 \%$ of the species were considered new to science. Most of the 23 known species have been reported from NE Atlantic coastlines and from higher latitudes in northern Subpolar and Polar Seas. At the family level, the harpacticoid fauna in the Porcupine Seabight did not seem to differ markedly from other deep-sea areas, with essentially the same abundant families. However, the presence of typically epifaunal taxa indicates that the hard substrates of the coral degradation zone provide an exceptional habitat. Further, harpacticoid composition and diversity of sediment and coral fragments were compared with similar substrates in a tropical reef lagoon (Zanzibar, Tanzania). Both regions harboured different fauna and the difference between coral and sediment was more obvious in the tropical lagoon. Species richness and evenness of the two microhabitats in the tropical lagoon were lower than in the deep sea.
\end{abstract}

Keywords: cold-water corals, harpacticoid copepods, species composition, north-east Atlantic, Porcupine Seabight.

RESUMEN: Harpacticoídeos (Crustacea: Copepoda) asociados a sustratos de CORAles de aguas frías en PorcuPINE SEABIGHT (NE ATLÁNTICO): COMPOSICIÓN ESPEĆ́fICA, DIVERSIDAD Y REFLEXIONES SOBRE EL ORIGEN DE LA FAUNA. - Por primera vez, se ha investigado la fauna de copépodos harpacticoídeos asociada a la zona de degradación del coral de arrecifes de Lophelia pertusa (Linneo, 1758), de Porcupine Seabight (NE Atlántico). El listado de especies de la zona de degradación del coral incluye 157 especies, 62 géneros y 19 familias. Las familias con mayor riqueza de especies fueron Ectinosomatidae (36 especies), Ameiridae (29 especies) y Argestidae (17 especies). En conjunto, al menos el $80 \%$ de las especies son consideradas nuevas para la ciencia. La mayoría de las 23 especies conocidas han sido citadas en las costas del NE Atlántico y en altas latitudes del mar Subpolar y Polar. A nivel de familia, la fauna harpacticoídea en Porcupine Seabight no parece ser muy diferente de la de otras áreas de fondos marinos profundos, presentando en esencia las mismas familias dominantes. Sin embargo, la presencia de taxones típicamente epifáunicos indica que los sustratos duros de la zona de degradación del coral proporcionan un hábitat excepcional. Además, la composición de copépodos harpacticoídeos y la diversidad de sedimento y fragmentos de coral muerto fueron comparados con sustratos similares en una laguna de arrecife tropical (Zanzíbar, Tanzania). Ambas regiones dan abrigo a fauna diferente, y la diferencia entre coral y sedimento fue más evidente en la laguna tropical. La riqueza específica y la equidad de ambos microhábitats en la laguna tropical fueron menores que en fondos marinos profundos.

Palabres clave: corales de aguas frías, copépodos harpacticoídeos, composición específica, NE Atlántico, Porcupine Seabight. 


\section{INTRODUCTION}

Cold-water corals occur in the upper part of the bathyal zone throughout the world. Lophelia pertusa (Linnaeus, 1758) is most frequently recorded from the continental margin of the NE Atlantic (Rogers, 1999; Freiwald, 2002). Previous studies dealing with the associated fauna on either living or dead $L$. pertusa have mainly focused on macro- and megafauna (e.g. Jensen and Frederiksen, 1992; Rogers, 1999). Henry and Roberts (2007) reported that the macrofauna on coral mounds is not locally endemic but typically derived from the regional species pool. However, a characteristic yet facultative reef fauna distinguishes coral mounds from other habitats in the Belgica Mound Province (Porcupine Seabight, NE Atlantic). Raes and Vanreusel (2005, 2006) presented the first study on the associated metazoan meiofauna and nematofauna of a cold-water coral degradation zone in the Porcupine Seabight. They concluded that the dead $L$. pertusa framework and associated substrates enable more taxa to be present and particularly favour harpacticoid copepods, naupliar larvae and polychaetes. The nematofauna associated with the large biogenic substrata is composed of a typical slope, sediment-dwelling, interstitial background community, supplemented with taxa adapted to an epifaunal life strategy. In the underlying sediment, the nematode communities are dominated by typical soft sediment slope taxa (Raes and Vanreusel, 2006).

Although harpacticoid copepods are a diverse and abundant part of the deep-sea meiobenthos, general knowledge on their species composition and distribution is still limited (Seifried, 2004). Even in the NE Atlantic Ocean, which is one of the best studied regions concerning the deep-sea meiobenthos, information on harpacticoid diversity and species composition remains remarkably scarce (Vincx et al., 1994). The present paper provides the first comprehensive study on the harpacticoid copepod fauna associated with dead cold-water coral substrates from the deep sea. We will assess whether a cold-water coral degradation zone in the Porcupine Seabight harbours a distinctive harpacticoid fauna compared to the surrounding soft-bottom deep-sea floor. Furthermore, we will discuss the possible affinities to fauna in other habitats which might be connected to these reefs.

Recently, Raes et al. (2008) studied community structure and habitat preferences of two typically epifaunal nematode families (Epsilonematidae and Draconematidae) in deep temperate (Porcupine Seabight) and shallow tropical (Kenya, Indian Ocean) coral degradation zones. Despite the strong environmental differences of these geographically and bathymetrically separated ecosystems, similar (and in some cases even morphologically identical) species were found, which emphasised the importance of microhabitat type in structuring the nematode community. For the harpacticoid copepod fauna, we will compare the composition in a cold-water coral degradation zone (Porcupine Seabight) with the fauna from similar substrates in a tropical reef lagoon (Zanzibar Island, Indian Ocean) (recently studied by Gheerardyn et al. (2008b)) and will assess whether diversities in the two degradation zones are of a similar order of magnitude.

\section{MATERIAL AND METHODS}

The material studied in this paper was collected during expeditions RV Belgica 00/16, 01/12 and 03/13 in the Porcupine Seabight (NE Atlantic Ocean), in June 2000, May 2001 and May 2003 respectively. Eight sites were sampled with a round box corer (Netherlands Institute for Sea Research, diameter 32 cm) (Fig. 1, Table 1). Six sampling sites in the coral degradation zone of Lophelia pertusa reefs yielded 6 sediment, 6 coral and 2 sponge samples. The material from the coral degradation zone was collected at depths between 880 and $1005 \mathrm{~m}$, with boxes 1, 2, 5 and 6 taken from the flanks of two seabed mounds in the Belgica Mound Province, and boxes 3 and 4 taken between these two mounds. In each case, the surface of the sediment was partly or entirely covered with several dead fragments of the cold-water coral Lophelia pertusa and skeletons of the glass sponge Aphrocallistes bocagei Schultze, 1886. After collecting the coral fragments and sponge skeletons separately, meiofauna of underlying sediment was sampled with three sediment cores (surface area $10 \mathrm{~cm}^{2}$ ). The underlying sediment mainly consisted of fine to medium sand and a more or less pronounced silt fraction (median grain size between 8.3 and $194.9 \mu \mathrm{m}$ ), and contained small fragments of both biogenic substrates, as well as some small mollusc shells and echinoid radioles. For samples of coral-free sediments, two boxcorers were taken to the west of the mounds in the Arwen Channel (box 7a and 7b) and two boxcorers to the east of the mounds (box 8a and 8b). Three sediment cores 

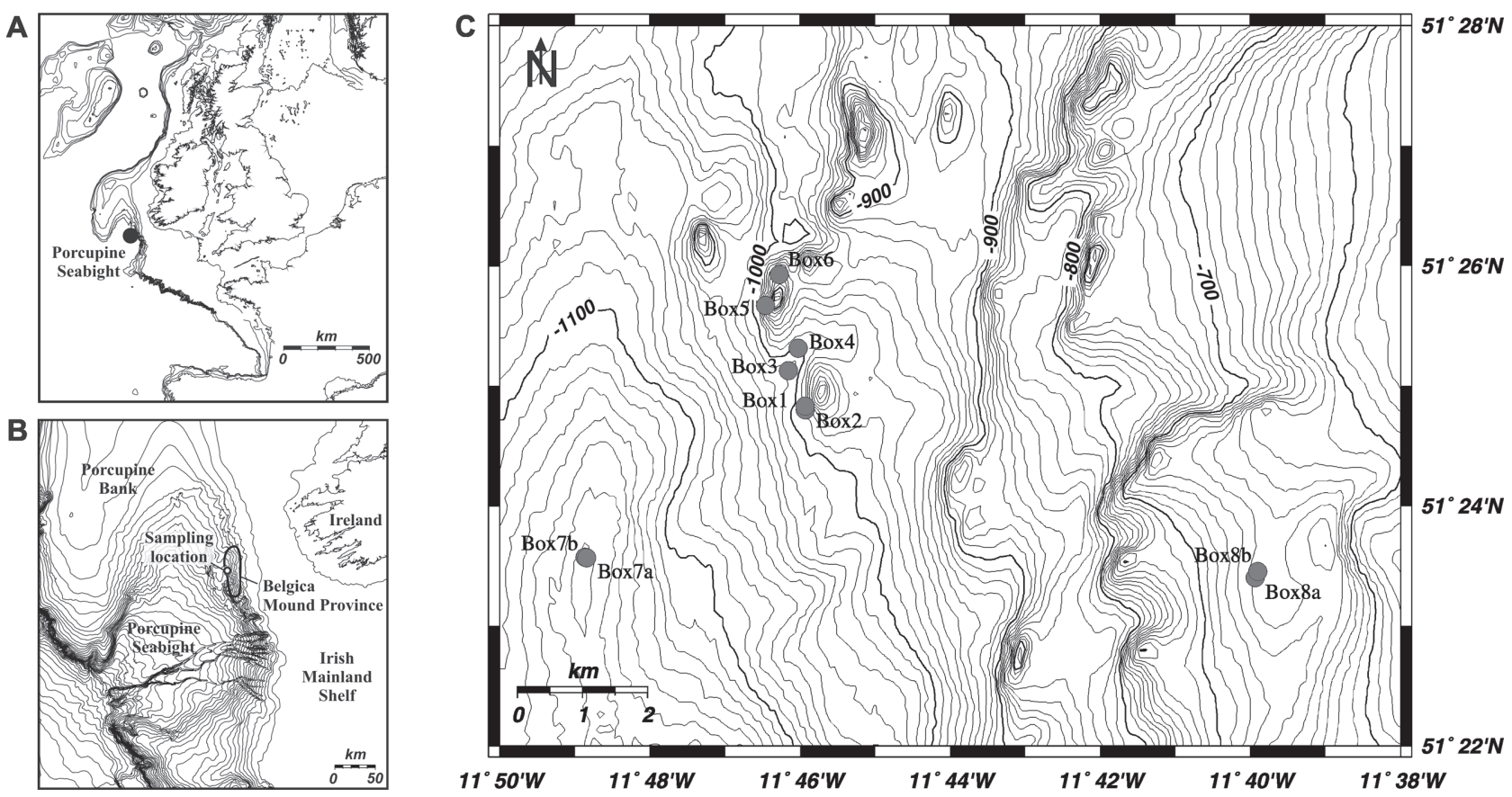

$11^{\circ} 50^{\prime} \mathrm{W}$

$11^{\circ} 48^{\prime} W$

FIG. 1. - (A) Location of the Porcupine Seabight (NE Atlantic Ocean) along the European continental margin, (B) sampling location in the
Belgica Mound Province, and (C) a detail showing the ridge of mounds in the Belgica Mound Province, with boxcorers $1-6$ taken in the coral degradation zone of two seabed mounds, and boxcorers 7a-b and 8a-b from coral-free sediments (multibeam bathymetry by courtesy of AWI Bremerhaven, contour interval at $10 \mathrm{~m}$ ).

TABLE 1. - Depth, date, geographical position, and microhabitats sampled per boxcorer taken at the Porcupine Seabight. (sed = underlying sediment, cor $=$ coral fragment, spo $=$ sponge skeleton)

\begin{tabular}{|c|c|c|c|c|c|}
\hline \multirow[t]{2}{*}{ Boxcorer } & \multirow[t]{2}{*}{ Date } & \multicolumn{2}{|c|}{ Coordinates } & \multirow[t]{2}{*}{ Depth (m) } & \multirow[t]{2}{*}{ Sample } \\
\hline & & Latitude & Longitude & & \\
\hline Box1 & 17.06 .2000 & $51^{\circ} 24.802^{\prime} \mathrm{N}$ & $11^{\circ} 45.924^{\prime} \mathrm{W}$ & 1005 & sed, cor, spo \\
\hline Box2 & 17.06 .2000 & $51^{\circ} 24.824{ }^{\prime} \mathrm{N}$ & $11^{\circ} 45.932^{\prime} \mathrm{W}$ & 1000 & sed, cor \\
\hline Box3 & 07.05 .2001 & $51^{\circ} 25.1290^{\prime} \mathrm{N}$ & $11^{\circ} 46.1553^{\prime} \mathrm{W}$ & 972 & sed, cor, spo \\
\hline Box4 & 07.05 .2001 & $51^{\circ} 25.3120^{\prime} \mathrm{N}$ & $11^{\circ} 46.0226^{\prime} \mathrm{W}$ & 969 & sed, cor \\
\hline Box5 & 07.05 .2001 & $51^{\circ} 25.6700^{\prime} \mathrm{N}$ & $11^{\circ} 46.4553^{\prime} \mathrm{W}$ & 950 & sed, cor \\
\hline Box6 & 07.05 .2001 & $51^{\circ} 25.9290^{\prime} \mathrm{N}$ & $11^{\circ} 46.2717^{\prime} \mathrm{W}$ & 880 & sed, cor \\
\hline Box7a & 25.05 .2003 & $51^{\circ} 23.572^{\prime} \mathrm{N}$ & $11^{\circ} 48.859^{\prime} \mathrm{W}$ & 1168 & sed \\
\hline Box7b & 25.05 .2003 & $51^{\circ} 23.567^{\prime} \mathrm{N}$ & $11^{\circ} 48.843^{\prime} \mathrm{W}$ & 1175 & sed \\
\hline Box8a & 25.05 .2003 & $51^{\circ} 23.403^{\prime} \mathrm{N}$ & $11^{\circ} 39.936^{\prime} \mathrm{W}$ & 649 & sed \\
\hline Box $8 b$ & 25.05 .2003 & $51^{\circ} 23.454^{\prime} \mathrm{N}$ & $11^{\circ} 39.901^{\prime} \mathrm{W}$ & 646 & sed \\
\hline
\end{tabular}

$\left(10 \mathrm{~cm}^{2}\right)$ were collected per boxcorer and copepods were taken from the upper three centimetres. All material was fixed with $4 \%$ buffered formaldehyde. At both coral-free sampling sites, the upper first centimetre layer consisted of fine to medium sand with a small silt fraction (median grain size between 153.6 and $189.3 \mu \mathrm{m}$ ). In total, a surface area of $180 \mathrm{~cm}^{2}$ of underlying sediment was collected from the coral degradation zone and $120 \mathrm{~cm}^{2}$ of sediment from the coral-free sites.

In the laboratory, each coral or sponge sample was rinsed thoroughly over $1 \mathrm{~mm}$ and $32 \mu \mathrm{m}$ sieves to collect macro- and meiofauna respectively. Meiofauna from the sediment was extracted by density gradient centrifugation, using Ludox HS40 (spe- cific density 1.18) as a flotation medium (Heip et al., 1985). The first 200 randomly encountered copepods per sample (or all copepods when less than 200 were present) were picked out and mounted in glycerine. All adult harpacticoids were identified to species using Lang (1948, 1965), Huys et al. (1996), Boxshall and Halsey (2004) and original species descriptions. Assignment of species to genera and families was in accordance with recent literature. The systematic status of Pseudotachidiidae Lang, 1936 and Rhynchothalestridae Lang, 1948 follows Willen (2000), the status of Miraciidae Dana, 1846 follows Willen (2000, 2002), and the status of Idyanthidae Lang, 1944, Neobradyidae Olofsson, 1917 and Zosimidae Seifried, 2003 follows Seifried (2003). 
TABle 2. - List of identified families, genera and species from the Porcupine Seabight. For each species, the number of collected specimens from the coral degradation zone is given (between parentheses). Number of collected specimens from coral-free sites 7 and 8 are provided separately ( ${ }^{7}$ or ${ }^{8}$ : from coral-free site 7 or 8 , respectively).

Family Ameiridae Monard, 1927

Ameira Boeck, 1865:

Ameiropsis Sars, 1907:

Filexilia Conroy-Dalton and Huys, 1997:

Leptomesochra Sars, 1911:

Malacopsyllus Sars, 1911:

Parapseudoleptomesochra Lang, 1965:

Pseudameira Sars, 1911:

Sarsameira Wilson, 1924:

Stenocopia Sars, 1907:

Ameirinae Lang, 1944 unidentified:

Family Ancorabolidae Sars, 1909

Ancorabolina George, 2006:

Laophontodes T. Scott, 1894:

Lobopleura Conroy-Dalton, 2004:

Family Argestidae Por, 1986

Argestes Sars, 1910:

Bodinia George, 2004:

Dizahavia Por, 1979:

Eurycletodes Sars, 1909:

Fultonia T. Scott, 1902:

Mesocletodes Sars, 1909:

Argestidae unidentified:

Family Canthocamptidae Sars, 1906

Bathycamptus Huys and Thistle, 1989:

Mesochra Boeck, 1865:

Canthocamptidae unidentified:

Family Cletodidae T. Scott, 1905

Cletodes Brady, 1872:

Enhydrosoma Boeck, 1872:

Family Ectinosomatidae Sars, 1903

Bradya Boeck, 1873:

Bradyellopsis Brian, 1924:

Ectinosoma Boeck, 1865:

Halectinosoma Lang, 1944:

Halophytophilus Brian, 1919:

Hastigerella Nicholls, 1935:

Klieosoma Hicks and Schriever, 1985 :

Lineosoma Wells, 1965:

Microsetella Brady and Robertson, 1873:

Parabradya Lang, 1944:

Peltobradya Médioni and Soyer, 1968:

Pseudobradya Sars, 1904:

Sigmatidium Giesbrecht, 1881:

Ectinosomatidae unidentified:

Family Harpacticidae Sars, 1904 Perissocope Brady, 1910:

Family Huntemanniidae Por, 1986 Metahuntemannia Smirnov, 1946: Talpina Dahms and Pottek, 1992:

Family Idyanthidae Lang, 1944 Idyanthe Sars, 1909:

Idyella Sars, 1906:

Nematovorax Bröhldick, 2005:

Idyanthidae unidentified:

Family Laophontidae T. Scott, 1905 Archesola Huys and Lee, 2000:

Heterolaophonte Lang, 1944: Laophonte Philippi, 1840:

Family Miraciidae Dana, 1846 Amphiascus Sars, 1905:

Amphiascoides Nicholls, 1941:

Haloschizopera Lang, 1944 :

Rhyncholagena Lang, 1944:

Robertgurneya Lang, 1944: sp. $1(37)$, sp. $2(2)$, sp. $3\left(28 ; 1^{7}\right)$, sp. 4 (1), sp. $5(1)$, sp. $6\left(1^{8}\right)$

sp. 1 (3), sp. 2 (2), sp. 3 (3), sp. 4 (2), sp. 5 (2), sp. 6 (1)

sp. 1 (3)

sp. 1 (16), sp. 2 (2)

new sp. 1 (4), new sp. 2 (1)

sp. 1 (3), sp. 2 (9)

sp. 1 (1), sp. $2\left(8 ; 1^{7}\right)$

sp. 1 (16), sp. 2 (4)

new sp. 1 (4), new sp. 2 (9), new sp. 3 (1)

sp. 1 (1), sp. 2 (1), sp. 3 (1), sp. 4 (1)

A. belgicae Gheerardyn and George, in press (1)

L. mourois Arroyo, George, Benito and Maldonado, 2003 (5)

L. expansa (Sars, 1908) (3)

new sp. 1 (5), new sp. 2 (2), new sp. 3 (2), new sp. 4 (1), new sp. 5 (1)

new sp. 1 (7)

new sp. $1(9)$

E. (O.) cf. similis (T. Scott, 1895) (7), new sp. $1\left(1^{7}\right)$, new sp. 2 (1)

F. cf. bougisi Soyer, 1964 (12), new sp. 1 (11)

M. guillei Soyer, 1964 (1), M. irrasus (T. and A. Scott, 1894) (1), new sp. 1 (1), new sp. 2 (2), new sp. 3 (2)

sp. 1 (3)

new sp. 1 (6), new sp. 2 (2), new sp. 3 (1)

M. pygmaea (Claus, 1863) (9)

sp. 1 (1), sp. $2(3)$, sp. 3 (2), sp. 4 (4), sp. 5 (6), sp. $6(5)$, sp. 7 (1), sp. 8 (1), sp. $9\left(1^{7}\right)$, sp. $10\left(1^{8}\right)$

sp. $1\left(1 ; 2^{8}\right)$, sp. $2\left(1^{8}\right)$, sp. $3\left(1^{8}\right)$

sp. 1 (1)

new sp. 1 (1), new sp. 2 (2)

new sp. 1 (1)

new sp. 1 (9), new sp. 2 (3), new sp. $3\left(1^{8}\right)$, new sp. 4 (3)

new sp. $1(1)$, new sp. $2\left(1^{8}\right)$, new sp. 3 (1)

H. lopheliae Gheerardyn, Seifried and Vanreusel, $2008\left(27 ; 1^{8}\right)$, new sp. 1 (13), new sp. 2 (4), new sp. $3\left(1^{7}\right)$

new sp. $1(2)$, new sp. $2\left(1^{8}\right)$

K. triarticulatum (Klie, 1949) (8), new sp. 1 (4), new sp. 2 (4)

new sp. 1 (1), new sp. $2\left(1^{7}\right)$

M. norvegica (Boeck, 1865) (16)

new sp. 1 (1), new sp. 2 (5)

new sp. $1(1)$

P. cf. banyulensis Soyer, 1974 (38), P. cf. peresi Soyer, 1974 (1), new sp. 1 (2), new sp. 2 (5), new sp. 3 (1), new sp. 4 (2), new sp. 5 (3), new sp. $6\left(1^{7}\right)$

S. cf. parvulum Mielke, 1974 (1), S. cf. triarticulatum Mielke, 1979 (3), new sp. 1 (7), new sp. 2 (4), new sp. 3 (2), new sp. 4 (12), new sp. 5 (45), new sp. $6\left(1^{7}\right)$

new sp. 1 (1), new sp. 2 (1)

new sp. 1 (27)

new sp. $1(1)$, new sp. $2\left(1 ; 1^{7}\right)$

new sp. $1\left(1^{7}\right)$

I. dilatata (Sars, 1905) (5), new sp. 1 (3), new sp. 2 (7), new sp. 3 (2), new sp. 4 (1)

I. major Sars, 1920 (1), new sp. 1 (1)

N. gebkelinae Bröhldick, 2005 (1)

new sp. 1 (3), new sp. 2 (1)

new sp. $1(1)$

new sp. $1(1)$

L. elongata Boeck, 1872 (5), new sp. 1 (14), new sp. 2 (2), new sp. 3 (7)

sp. $1\left(26 ; 2^{8}\right)$, sp. $2(7)$, sp. $3\left(1^{8}\right)$

sp. $1\left(6 ; 2^{8}\right)$

sp. $1\left(9 ; 3^{7}\right)$

sp. $1(11)$

sp. $1\left(2^{8}\right)$ 
TABLE 2 (cont.). - List of identified families, genera and species from the Porcupine Seabight. For each species, the number of collected specimens from the coral degradation zone is given (between parentheses). Number of collected specimens from coral-free sites 7 and 8 are provided separately ( ${ }^{7}$ or ${ }^{8}$ : from coral-free site 7 or 8 , respectively).

Family Neobradyidae Olofsson, 1917 Marsteinia Drzycimski, 1968: Neobradyidae unidentified:

Family Normanellidae Lang, 1944 Sagamiella Lee and Huys, 1999:

Family Novocriniidae Huys and Iliffe, 1998 Atergopedia Martínez Arbizu and Moura, 1998: A. vetusta Martínez Arbizu and Moura, 1998 (3), new sp. 1 (1)

Family Paramesochridae Lang, 1944 Diarthrodella Klie, 1949: Kliopsyllus Kunz, 1962:

Leptopsyllus T. Scott, 1894 Paramesochra T. Scott, 1892: Scottopsyllus Kunz, 1962: Paramesochridae unidentified:

Family Pseudotachidiidae Lang, 1936 Cylindronannopus Coull, 1973: Idomene (?) Philippi, 1843: Pseudomesochra T. Scott, 1902:

new sp. 1 (5), new sp. 2 (1), new sp. 3 (3)

new sp. 1 (6)

new sp. $1\left(2^{8}\right)$
Xylora Hicks, 1988:

Pseudotachidiidae unidentified:

Family Rhynchothalestridae Lang, 1948 Rhynchothalestris Sars, 1905:

Family Tegastidae Sars, 1904 Tegastes Norman, 1903:

Family Tetragonicipitidae Lang, 1944 Tetragonicipitidae new gen. 1:

Family Zosimidae Seifried, 2003 Zosime Boeck, 1872:

Harpacticoida incertae sedis Parameiropsis Becker, 1974:

Unidentified sp. 1 (1)

Unidentified sp. 2 (2)
D. cf. orbiculata Klie, 1949 (1)

new sp. $1\left(1^{7}\right)$, new sp. $2\left(1^{8}\right)$

new sp. 1 (6), new sp. $2\left(1^{8}\right)$

new sp. $1(8)$, new sp. $2(3)$, new sp. $3(2)$, new sp. $4\left(2 ; 1^{7}\right)$, new sp. $5\left(1^{7}\right)$

S. (Sc.) cf. robertsoni (T. and A. Scott, 1895) (1)

sp. $1\left(1^{7}\right)$

new sp. 1 (2)

sp. 1 (2), sp. 2 (5)

new sp. 1 (31), new sp. $2(8)$, new sp. $3(6)$, new sp. 4 (45), new sp. 5 (11), new sp. 6

(3), new sp. 7 (3)

new sp. 1 (2), new sp. 2 (10)

sp. 1 (2)

new sp. 1 (7)

sp. 1 (1)

new sp. 1 (6)

Z. bergensis Drzycimski, 1968 (4; 18), Z. paramajor Bodin, 1968 (1), Z. pacifica Fiers, $1991\left(1^{8}\right)$, new sp. $1\left(1^{7}\right)$

P. antennafortis Corgosinho and Gheerardyn, 2009 (1)
Rarefaction curves (Sanders, 1968), calculated using the methods of Hurlbert (1971), were used to compare species richness. Equitability of the copepod fauna was studied based on species' abundance distributions as k-dominance curves (Lambshead et al., 1983). Calculations were done using the PRIMER5 software (Clarke and Gorley, 2001).

Species composition and diversity of dead coral fragments and underlying sediment are compared with similar substrates from a tropical reef lagoon along the eastern coast of Zanzibar Island (Tanzania). Meiofauna samples were collected in August 2004 at two locations, Matemwe (5'52'S, 39²1'E) and Makunduchi $\left(6^{\circ} 25^{\prime} \mathrm{S}, 39^{\circ} 34^{\prime} \mathrm{E}\right)$. The distance between the two locations is $70 \mathrm{~km}$ and sampling occurred during low tide, under a water cover of $0.5 \mathrm{~m}$. At each location, three replicates were taken at a distance of five metres from each other, at approximately $400-500 \mathrm{~m}$ from the beach. For each replicate, a round, metal core (diameter $30 \mathrm{~cm}$ ) was placed onto the sediment to delimit the sampling area. Within this metal core, meiofauna of coral sand was sampled with one sediment core (surface area $10 \mathrm{~cm}^{2}$ ). The dead coral fragment was taken out manually and put directly in a plastic bag. In total, a surface area of $60 \mathrm{~cm}^{2}$ of coral sand was collected from the tropical reef lagoon. Further processing of the samples and laboratory analyses are described in Gheerardyn et al. (2008b).

\section{RESULTS}

In total, 901 adult harpacticoids were analysed from the Porcupine Seabight (860 from the coral degradation zone, 18 from coral-free sediments at site 7 and 23 from coral-free sediments at site 8 ) and this yielded 181 species (Table 2), two of which could not be assigned to any family and were treated as Harpacticoida incertae sedis. The remaining 179 species were spread over 20 families. At present, 22 species cannot be assigned unequivocally to a known genus and are assigned to their respective suprageneric taxon (e.g. subfamily Ameirinae). The other 157 species were spread over 66 genera, with one genus being new in Tetragonicipitidae. Due to the high number of species, it was necessary to restrict the processing and therefore 54 species 


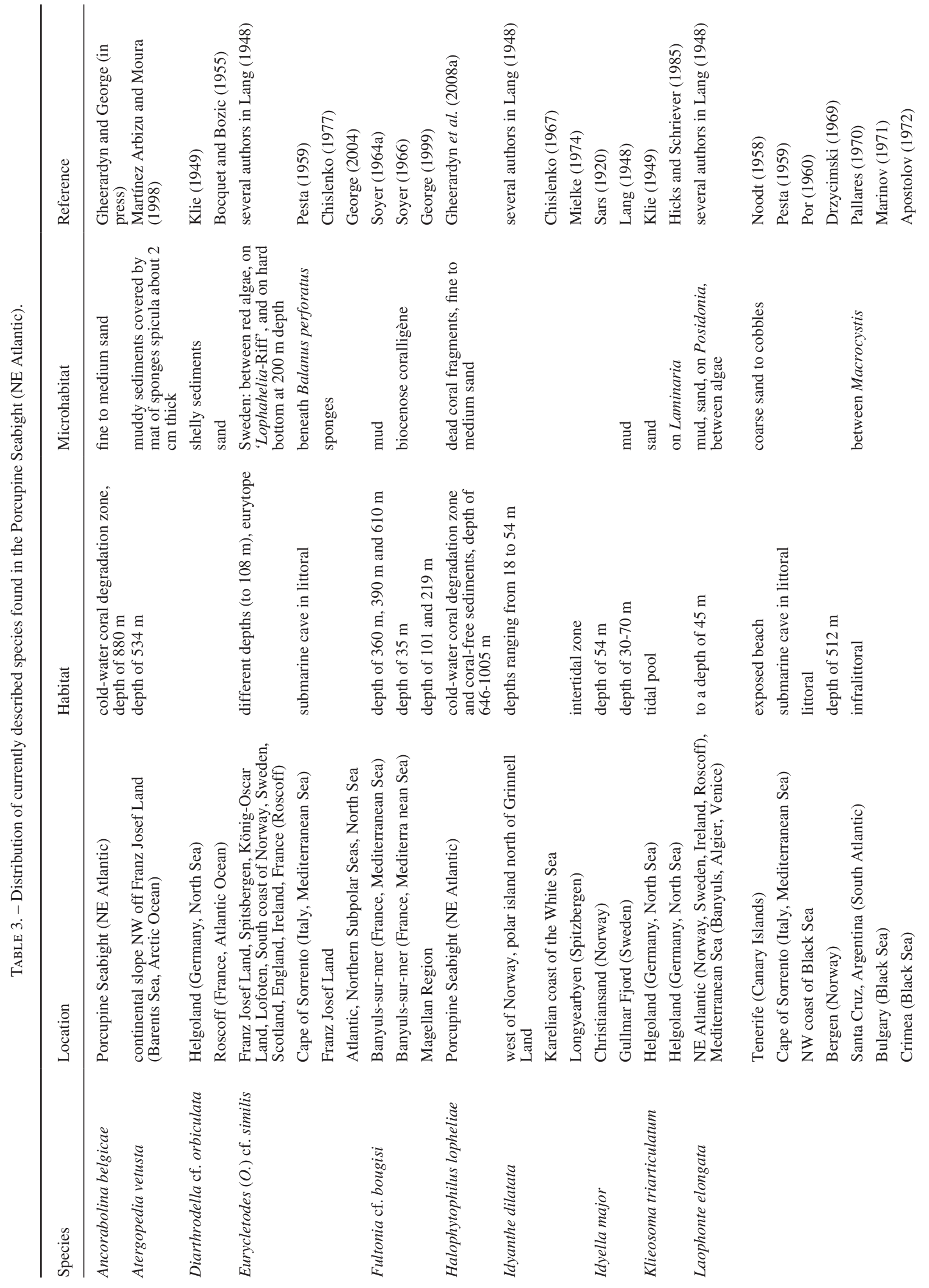



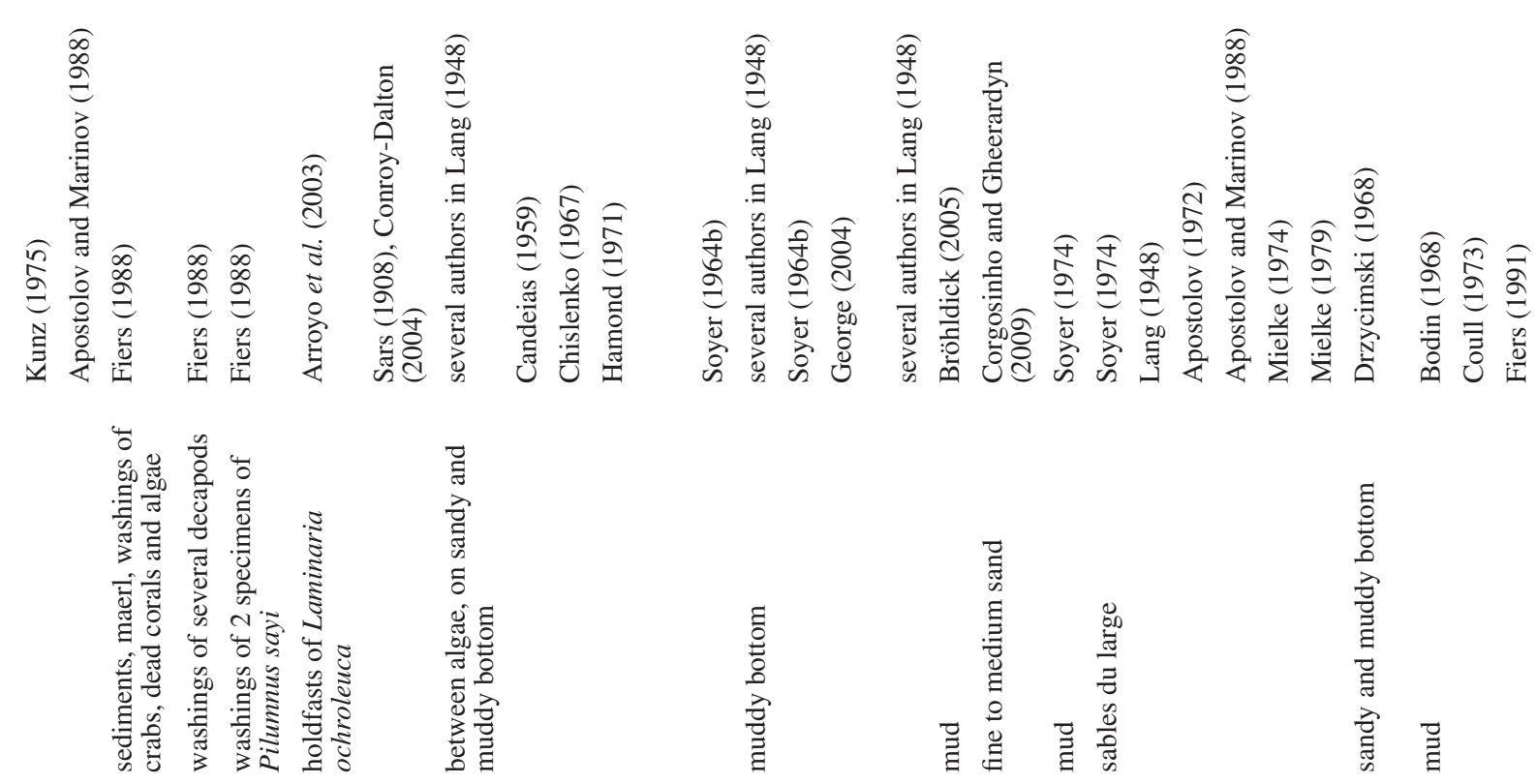

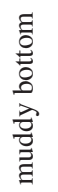

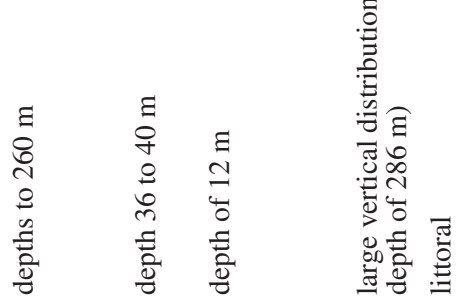

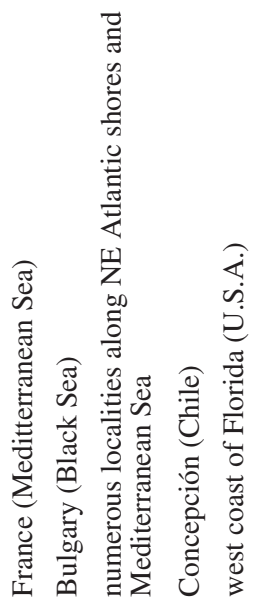

$\stackrel{\Xi}{\circ}$

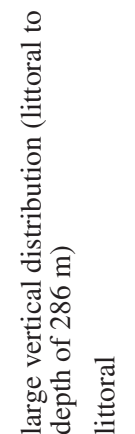

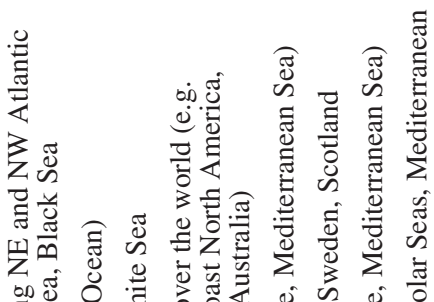

0.

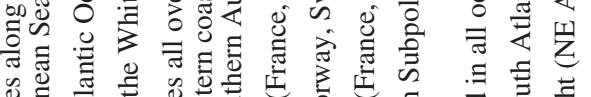

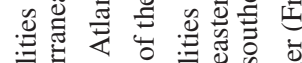

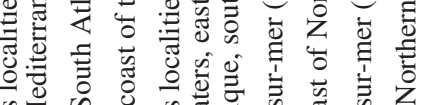

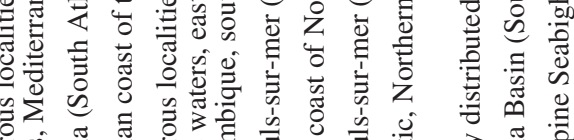

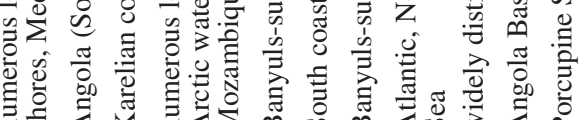

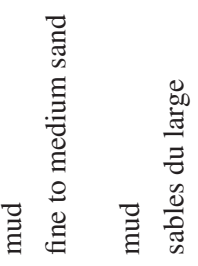

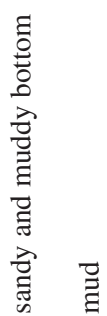

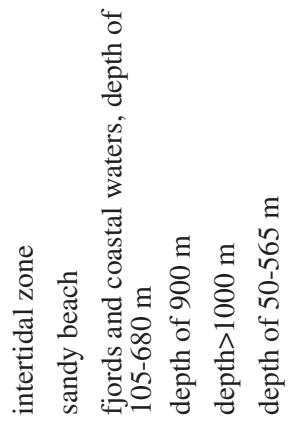

ఫ్
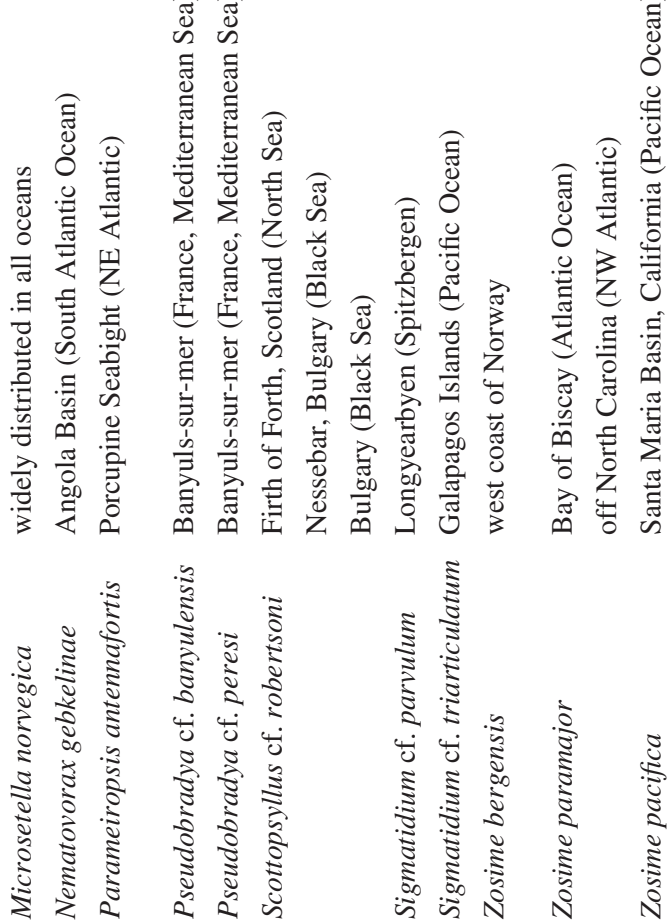

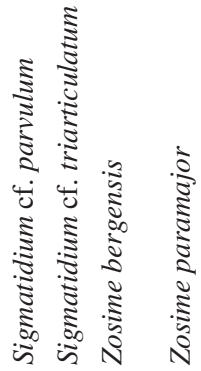


within Ameirinae, Canthocamptidae, Cletodidae and Miraciidae were determined to morphospecieslevel. However, 127 species were carefully checked against original species descriptions and, of these, 104 species (or $81.9 \%$ ) were new to science. The identification of certain species ( 8 of the 23 known) has to be considered with some reservations (specific names indicated with cf.). Until now, three of the new species (Halophytophilus lopheliae Gheerardyn, Seifried and Vanreusel, 2008; Parameiropsis antennafortis Corgosinho and Gheerardyn, 2009; Ancorabolina belgicae Gheerardyn and George, in press) have been described (Gheerardyn et al., 2008a; Corgosinho and Gheerardyn, 2009; Gheerardyn and George, in press) and one species (Atergopedia nov. sp. 1) is currently under description.

The samples of the coral degradation zone yielded 157 species belonging to 62 genera and 19 families. In the coral degradation zone, Ectinosomatidae, Ameiridae and Argestidae were the most species-rich families with 36, 29 and 17 species respectively. Pseudotachidiidae, Canthocamptidae and Idyanthidae were represented by 13, 12 and 10 species respectively. The following families were represented by between seven and two species each (in order of decreasing number of species): Paramesochridae, Laophontidae, Miraciidae, Neobradyidae, Ancorabolidae, Cletodidae, Zosimidae, Huntemanniidae and Novocriniidae. The remaining four families (Harpacticidae, Rhynchothalestridae, Tegastidae and Tetragonicipitidae) were monospecific. The most species-rich genera were Pseudobradya, Pseudomesochra and Sigmatidium (each 7 spp.), and Ameiropsis (6 spp.).

The samples from the two coral-free sites added 24 species, 4 genera and 1 family to the complete species list of the Porcupine Seabight. 16 species were colleted from site 7 and 18 species from site 8 . Each site shared five species with the coral degradation zone. None of the species was present at the two coral-free sites.

\section{Distribution of currently described species found in the Porcupine Seabight}

A list of all identified species and data on their geographical and bathymetrical distribution is presented in Table 3. Most of the species (19) have been reported from localities along NE Atlantic coastlines and from higher latitudes in the northern Subpolar and Polar Seas. Laophonte elongata shows a much wider distribution throughout the Atlantic Ocean, including the Mediterranean Sea, the Black Sea and the Chilean Pacific coast. Furthermore, two of these species have also been found in the Mediterranean Sea (Eurycletodes similis and Mesocletodes irrasus), one in the Black Sea (Scottopsyllus robertsoni) and one in the deep NW Atlantic (Zosime paramajor). Up to now, three species were restricted to the Mediterranean Sea (Mesocletodes guillei, Pseudobradya banyulensis and $P$. peresi), while Fultonia bougisi showed a disjunct distribution with reports from the Mediterranean Sea and the Magellan region. Two species can be considered as cosmopolitan species (Mesochra pygmaea and Microsetella norvegica). Until now, 12 species (including four identified with reservations) were known from their type-locality only, with Nematovorax gebkelinae (from Angola Basin) and Zosime pacifica (from California, Pacific Ocean) the most remarkable in view of the remote location in which they were found.

Certain species (such as Fultonia bougisi, Laophonte elongata, Mesochra pygmaea, Mesocletodes irrasus, Zosime bergensis and Z. pacifica) show a large vertical distribution (eurybathyal) and seem to be capable of penetrating into deeper, bathyal waters. Six species (Ancorabolina belgicae, Atergopedia vetusta, Halophytophilus lopheliae, Nematovorax gebkelinae, Parameiropsis antennafortis, Zosime paramajor) are exclusive deep-sea species (so far only occurring below $200 \mathrm{~m}$ depth), while all other species have been mostly reported from littoral-sublittoral areas. It is interesting to note that Lang (1948) reported Eurycletodes similis from the 'Lophahelia-Riff' (probably a misspelling of Lophohelia, synonym of Lophelia) near Bohuslän (west coast of Sweden). In addition, Fiers (1988) found Laophonte elongata from washings of dead corals collected at a depth of 240-260 m, north of Shetland in the Atlantic Ocean. Most of the known species have been collected from muddy and sandy bottoms, although certain species (Klieosoma triarticulatum, Laophonte elongata, Laophontodes mourois and Mesochra pygmaea) seem to show a preference for phytal environments.

\section{Comparison with the harpacticoid fauna in a tropical reef lagoon}

\section{Composition}

At the family level, it was clear that both examined regions harboured different faunas and that the 


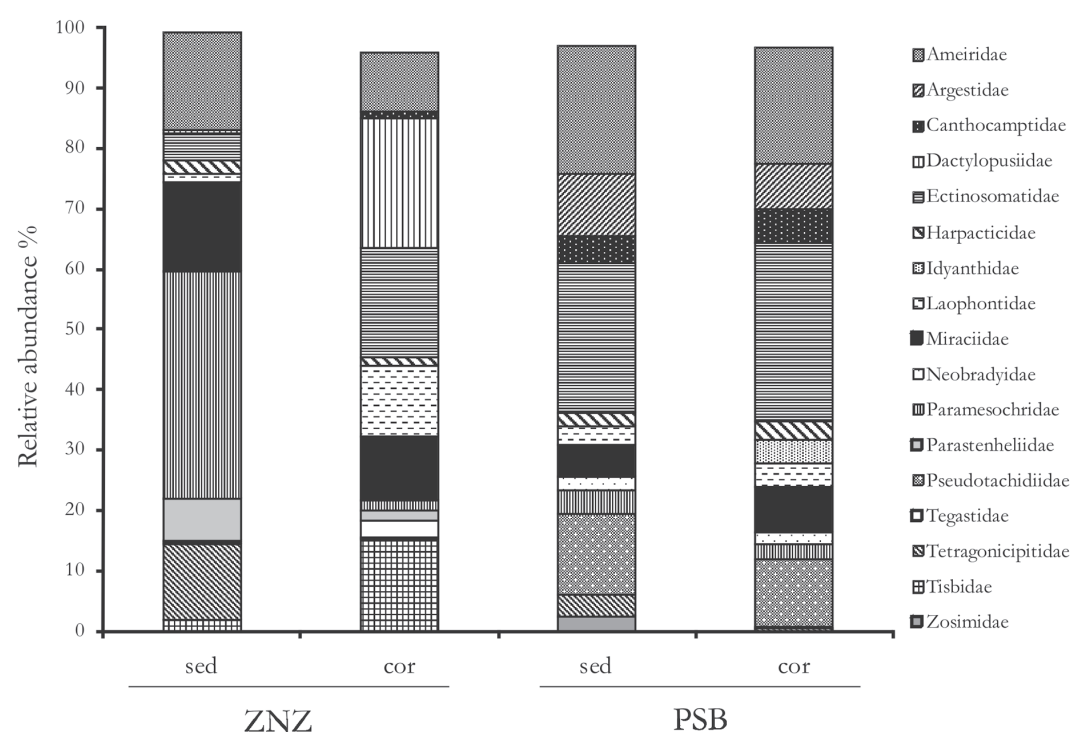

FIG. 2. - Harpacticoid family composition per microhabitat (sed: sediment, cor: coral) in the tropical lagoon on Zanzibar (ZNZ) and the coldwater coral degradation zone at the Porcupine Seabight (PSB), based on pooled samples per microhabitat. Families with a relative abundance $>2 \%$ in at least one microhabitat (in ZNZ or PSB) are given.

distinction between coral and sediment was clearer in the tropical lagoon (Fig. 2). In total, 29 families were recognised, 13 of which were shared by the two regions. Tropical coral fragments were characterised by high abundance of Dactylopusiidae, Ectinosomatidae, Tisbidae, Laophontidae and Miraciidae (more than $10 \%$ of the relative abundance each), while the coral sand was distinguished by the dominance of Paramesochridae, Tetragonicipitidae, Miraciidae and Ameiridae (more than $10 \%$ of the relative abundance each). In both microhabitats of the cold-water coral degradation zone, Ameiridae, Argestidae, Ectinosomatidae, Miraciidae and Pseudotachidiidae were the most abundant families (more than $5 \%$ of the relative abundance in each of the microhabitats). In total, 101 genera were identified, only 19 of which were shared by the two regions. 47 genera were restricted to the Porcupine Seabight and 35 to the tropical lagoon.

\section{Species diversity}

From the tropical substrates (sediment and coral), 1472 adult individuals were analysed, which belonged to 112 species. Although fewer individuals (705) were processed from sediment and coral samples in the Porcupine Seabight, distinctly more species (146) were found. Rarefaction curves of pooled samples per microhabitat in the tropical lagoon at Zanzibar and the deep sea of the Porcupine Seabight indicated a similar trend with a higher diversity

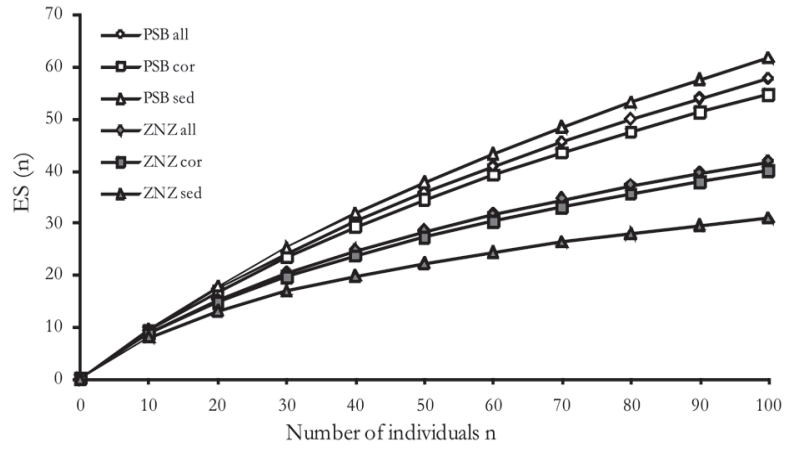

FIG. 3. - Rarefaction curves for pooled samples per microhabitat (sediment: sed, cor: coral) and for the combined community in the two microhabitats (all), in the cold-water coral degradation zone at the Porcupine Seabight (PSB) and the tropical lagoon on Zanzibar (ZNZ). ES (n), expected number of species.

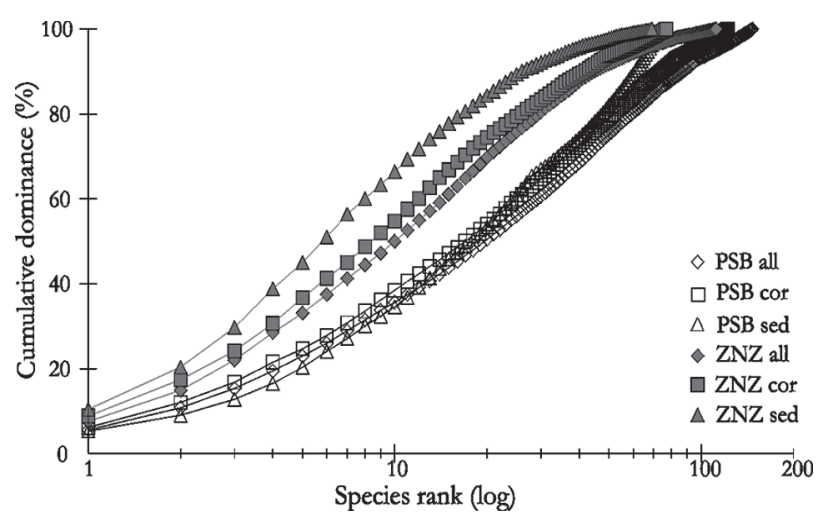

FIG. 4. - K-dominance curves for pooled samples per microhabitat (sediment: sed, cor: coral) and for the combined community in the two microhabitats (all), in the cold-water coral degradation zone at the Porcupine Seabight (PSB) and the tropical lagoon on Zanzibar (ZNZ). 
in the Porcupine Seabight (Fig. 3). The expected number of species (ES) for the two coral-free sites $(\operatorname{ES}(10)=9.3$ at site $7 ; \operatorname{ES}(10)=9.1$ and $\operatorname{ES}(20)=$ 16.2 at site 8) coincides with rarefaction curves of the cold-water coral degradation zone. Assemblages in the cold-water coral degradation zone showed a more even distribution than in the tropical lagoon, as shown by K-dominance curves (Fig. 4).

\section{DISCUSSION}

The present study is the first characterisation of the harpacticoid copepod fauna associated with cold-water coral substrates in the deep sea. Previous meiofauna studies have focused on the composition at a higher taxon level or the nematofauna of Lophelia pertusa reef degradation zones in the Belgica Mound Province (Porcupine Seabight, north-east Atlantic) (Raes and Vanreusel, 2005, 2006).

\section{Harpacticoid fauna of the Porcupine Seabight}

In the two examined microhabitats (corals and sediment) of the cold-water coral degradation zone, Ameiridae, Argestidae, Ectinosomatidae, Miraciidae and Pseudotachidiidae were the most abundant families. The two coral-free sampling sites yielded too few specimens to compare with the coral degradation zone and assess the influence of coral fragments on species composition and diversity. Therefore, emphasis has been placed on making comparisons with deep-sea studies on soft sediments to assess whether the coral degradation zone harbours a specific fauna. The most abundant families of the coral degradation zone correspond remarkably well to the most abundant of 19 families reported from two abyssal, muddy sites in the Angola Basin, from a water depth of about $5400 \mathrm{~m}$ (i.e. Pseudotachidiidae, Argestidae, Ameiridae, Ectinosomatidae and $\mathrm{Ne}-$ obradyidae) (Rose et al., 2005). In the present study, the assignment of species to genera and families is in accordance with recent literature as is the case in Rose et al. (2005). Vincx et al. (1994) reported the assemblages in the deep north-east Atlantic as dominated by Cletodidae, Diosaccidae, Ectinosomatidae, Tisbidae and Cerviniidae. However, at the time, certain genera were assigned to different families. The same caution is recommended when comparing with other studies. Ahnert and Schriever (2001) reported Ameiridae, Ectinosomatidae, Argestidae, Tisbidae (the majority of the specimens belonging to Zosime and Pseudozosime, which now belong to Zosimidae) and Neobradyidae as the dominant families in the deep sea of the SE Pacific ocean. In Sagami Bay (central Japan, at $1430 \mathrm{~m}$ depth), Miraciidae, Ectinosomatidae, Ameiridae and Tisbidae (with species of Idyellopsis and Zosime, which now belong to Idyanthidae and Zosimidae respectively) were the most abundant of the 13 harpacticoid families (Shimanaga et al., 2004).

At the family level, the copepod fauna of the coral degradation zone does not seem to differ markedly from other deep-sea studies on soft slope and abyssal sediments. Certain genera, such as Bradya, Eurycletodes, Malacopsyllus, Marsteinia, Mesocletodes, Pseudomesochra and Zosime, are typically found in any deep-sea study (Hicks and Coull, 1983; Seifried, 2004) and are also present in the Porcupine Seabight. While other families, genera and species do occur, detailed comparison at genus or even species level is restricted as no complete diversity analysis has been made of north-east Atlantic copepod communities (Vincx et al., 1994). The study of deepsea harpacticoids from the Great Meteor Seamount (which reaches about $270 \mathrm{~m}$ depth) by George and Schminke (2002) is at present the most closely situated study area, located west of the Canary Islands in the subtropical North Atlantic. George and Schminke (2002) detected 28 supraspecific taxa with Paramesochridae, Ectinosomatidae, Diosaccidae and Tisbidae as the most abundant. Of the 11 suprageneric taxa, which were analysed at species level, Argestidae was the most species-rich with seven genera and 40 species (in the Porcupine Seabight, this family consists of six genera and 18 species). Most of the suprageneric taxa from the Great Meteor Seamount were also present at the Porcupine Seabight, apart from Canuellidae, Cerviniidae, Cylindropsyllinae, Leptastacidae, Leptopontiidae and Styracothoracidae.

Harpacticoids exhibit an obvious and enormous variety of morphological forms as adaptations to special conditions in various marine habitats (Noodt, 1971). Body shape often reveals information regarding habitat type and it has been noticed that phytal associates generally possess a modified P1 which is strongly prehensile (Bell et al., 1987). Certain taxa of the coral degradation zone have a morphology which appears typically epifaunal (such as in Lobopleura, Peltobradya (depressed); Idyanthe, Idyella (fusiform depressed); Tegastes (laterally compressed)) and 
some of the identified species (Klieosoma triarticulatum, Laophontodes mourois, Mesochra pygmaea, Laophonte elongata) have even been reported from the washings of macroalgae (Lang, 1948; Hicks and Schriever, 1985; Arroyo et al., 2003). So far, deepsea tegastids have only been recorded from hardsubstrate nutrient-rich environments (Gollner et al., 2008). The occurrence of Tegastes in a coral sample again points to a preference of deep-sea tegastids for hard substrates. Furthermore, the occurrence of four ectinosomatid genera with prehensile first legs is exceptional in the deep sea and represents an indication of the specific nature of this habitat (Gheerardyn et al., 2008a). It seems that the hard biogenic substrates of the coral degradation zone provide a suitable habitat for these epifaunal harpacticoids. However, knowledge of the harpacticoid fauna in the NE Atlantic is at present too limited to assess to what extent the taxonomic composition is modified by the presence of these complex, hard substrates compared to the surrounding soft-bottom deep sea.

\section{Comparison with the harpacticoid fauna in a tropical reef lagoon}

\section{Composition}

Comparison of the family composition of sediment and dead coral fragments in the tropical lagoon of Zanzibar and the deep sea of the Porcupine Seabight indicates that the two regions harbour different faunas. Families like Ameiridae, Argestidae, Ectinosomatidae, Miraciidae and Pseudotachidiidae are typically abundant in the soft-bottom deep sea, and are also important in the examined microhabitats of the cold-water coral degradation zone. Certain families with a preference for deep-sea habitats, e.g. Argestidae, Neobradyidae, Pseudotachidiidae and Zosimidae (Seifried, 2004; George, 2004), were only found in the Porcupine Seabight and were absent in the tropical lagoon. The phytal families Dactylopusiidae and Tisbidae are very rare in the deep sea (Seifried, 2004) and were restricted to the tropical lagoon. Several families (Ameiridae, Ectinosomatidae, Miraciidae), are important in both regions, but these taxa are abundant in all marine habitats and are also generally important in all deep-sea studies. The difference in community structure between both regions is even more evident at the genus level, with only $18.8 \%$ of the total number of genera being shared. It is plausible that the extremely different en- vironmental conditions and evolutionary histories of both geographically and bathymetrically separated ecosystems are responsible for this difference in community structure, despite the presence of comparable substrates.

The distinction between coral and sediment is more obvious in the tropical lagoon than in the cold-water coral degradation zone. The tropical coral fragments contained a specific assemblage composed of typical phytal taxa (such as Tisbidae and Dactylopusiidae) along with other eurytopic and sediment-dwelling forms (Gheerardyn et al., 2008b). In the tropical lagoon, there is a large variety of habitat types (such as seagrasses, fossilised coral reef, seaweed farms), and these habitats might supply the phytal and epibenthic taxa which are present on the coral fragments. In the deep-sea environment, the number and occurrence of different substrate types (outside of the coral habitats) is much more limited. It is possible that most of the associated fauna is recruited from the surrounding soft sediments and this might explain the apparent lack of difference at the family level between sediment and coral substrates. This observation might also reflect differences in sampling between the two regions. In the cold-water coral degradation zone, the sediment could only be sampled from directly underneath the sampled coral fragments, while in the tropical lagoon the core was inserted in the sediment just next to the coral fragments.

\section{Species diversity}

Tropical coral reefs are known as the most taxonomically diverse of all marine ecosystems (Knowlton, 2001). Recently, it has been stated that the diversity of Lophelia pertusa cold-water coral reefs might be of a similar order of magnitude to that of some shallow-water coral reefs (Rogers, 1999). The present study aimed to compare species diversity of harpacticoid copepods associated with tropical and cold-water coral substrates. Although the large differences in sampling scale and effort (two sites $70 \mathrm{~km}$ apart along the Zanzibari coast versus six sites within a range of $2 \mathrm{~km}$ in the Porcupine Seabight) restrict comparisons, it seems that species richness and evenness of both microhabitats in the tropical lagoon are lower than in the deep sea. This would not be unexpected as the deep sea is known for its surprisingly high species diversity (Thistle, 1978; Seifried, 2004). 


\section{Reflections on the origin of the fauna}

At the family level, the harpacticoid fauna of the cold-water coral degradation zone does not seem to differ strongly from deep-sea studies of soft-bottom communities. However, at present, it is difficult to assess to what extent the composition at the genus or species level in this specific habitat is different from the surrounding soft-bottom deep sea. Evidently, there is an urgent need for information on the harpacticoid assemblages of sediments outside the coral degradation zone, and of the European continental slopes more generally. Whether the high percentage of new species reflects the specificity of the harpacticoid community in this habitat has to be considered after more systematic investigations of neighbouring Atlantic regions. An important question to solve is what the affinities with other habitats are of the fauna found in Lophelia pertusa reefs.

We propose three hypotheses for the colonisation of this habitat:

(1) The majority of associated species are recruited from the background community and are thus present in the local geographical area. These species could be considered as facultative inhabitants of the coral degradation zone. As a consequence, regional diversity would not be increased substantially by the presence of these coral reefs. Nevertheless, the complex habitat-providing structures may increase abundance and species richness locally and therefore represent patches with high harpacticoid diversity. However, the presence of typically epifaunal taxa points to unique species associated with the coral substrates.

(2) Another possibility is that there is an exchange with shallow water areas. One piece of evidence that may support this is that some of the identified species show a large bathymetric distribution from the shallow subtidal (or even the littoral) to bathyal depths. Certain species have only been reported from shallow waters so far. This would indicate that an appropriate substrate (and related environmental conditions) is more important than water depth. Lophelia pertusa reefs occur along the European continental margin with their main depth distribution between 200 and $1000 \mathrm{~m}$ (Rogers, 1999). In Norway, these reefs occur in fjords where they may penetrate up to within $50 \mathrm{~m}$ of the surface (Rogers, 1999; Fosså et al., 2002), forming a connection with shallow water habitats.
Furthermore, some of the identified species (e.g. Idyanthe dilatata, Idyella major, Laophonte elongata, Lobopleura expansa, Zosime bergensis) have even been reported from Norwegian fjords.

(3) Recently, De Mol et al. (2002, 2005) hypothesised that deep-water coral larvae may have been transported along the pathway of the Mediterranean Outflow Water (MOW) along the European continental margin from a southern source, potentially the Mediterranean Basin. Following this hypothesis, Raes et al. (2009) proposed that at least part of the nematofauna associated with $L$. pertusa fragments could follow the same trajectory as the larvae of this coral species, resulting in a co-occurrence of the coral and these nematodes. Accordingly, the source for colonisation would be somewhere in the Mediterranean Sea or near the MOW outflow point in the North Atlantic. In analogy herewith, for the harpacticoid copepod fauna the MOW might form a connection with the Mediterranean Sea, where several of the identified species have been recorded.

\section{ACKNOWLEDGEMENTS}

The first author acknowledges a postdoctoral research grant from the Special Research Fund (Ghent University, BOF). The second author is a postdoctoral fellow of the Research Foundation - Flanders (FWO). This research was conducted within the framework of the HERMES project (EC Sixth Framework Research Programme under the priority 'Sustainable Development, Global Change and Ecosystems'), the national FWO Research Project G.0199.03 'A Comparative Study of the Meio-Epifauna Associated with Tropical and Cold-Water Coral Reefs' and the UGent-BOF-GOA research project $01 \mathrm{GZ} 0705$ 'Biogeography and Biodiversity of the Sea'. The present study was supported by a small grant from the Taxonomy Clearing System (MarBEF). This publication is contribution number MPS-09007 of MarBEF. María Candás Romero (University of Santiago de Compostela) is kindly thanked for the Spanish translation of the summary and Dr. D. Van Rooij (Ghent University) for making the map of the Porcupine Seabight. We are grateful to two anonymous reviewers and the Chief Editor who made valuable suggestions for improvement of the manuscript. 


\section{REFERENCES}

Ahnert, A. and G. Schriever. - 2001. Response of abyssal Copepoda Harpacticoida (Crustacea) and other meiobenthos to an artificial disturbance and its bearing on future mining for polymetallic nodules. Deep-Sea Res. Part II, 48: 3779-3794.

Apostolov, A. - 1972. Catalogue des Copépodes Harpacticoïdes marins de la Mer Noire. Zool. Anz., 188(3-4): 202-254.

Apostolov, A. and T. Marinov. - 1988. Copepoda, Harpacticoida, "Fauna Bulgarica", 18. Aedibus Acad. Scient. Bulgaricae, Sofia, $1-384$.

Arroyo, N.L., K.H. George, J. Benito and M. Maldonado. - 2003. A new species of Ancorabolidae (Copepoda, Harpacticoida) from the northern coast of Spain: Laophontodes mourois sp. $\mathrm{n}$. Hydrobiologia, 498: 169-176.

Bell, S.S., K. Walters and M.O. Hall. - 1987. Habitat utilization by harpacticoid copepods: a morphometric approach. Mar. Ecol. Prog. Ser., 35: 59-64

Bocquet, C. and B. Bozic. - 1955. Idyanthopsis psammophila, gen. et sp. n., Tisbidae des sables de Roscoff. Arch. Zool. Exp. Gén., 93: $1-9$.

Bodin, P. - 1968. Copépodes Harpacticoïdes des étages bathyal et abyssal du Golfe de Gascogne. Mem. Mus. Natl. Hist. Nat., 55: $1-107$.

Boxshall, G.A. and S.H. Halsey. - 2004. An Introduction to Copepod Diversity. The Ray Society, Andover, United Kingdom.

Bröhldick, K.S.T. - 2005. A new taxon of Idyanthidae (Copepoda, Harpacticoida) from the deep sea of the Angola Basin. Org. Divers. Evol., 5: 43-57.

Candeias, A. - 1959. Contribution to knowledge of the harpacticoids (Crustacea Copepoda) from the littoral of Angola. Publ. Cult. Cia. Diamant. Angola, 45: 79-104.

Chislenko, L.L. - 1967. Copepoda Harpacticoida of the Karelian coast of the White Sea. Proc. White Sea Biol. Stat., Zool. Inst., 7(15): 48-196.

Chislenko, L.L. - 1977. Harpacticids (Copepoda, Harpacticoidea) from sponges of Franz Josef Land. Exploration of the Fauna of the Seas, 14(22): 237-276.

Clarke, K.R. and R.N. Gorley. - 2001. PRIMER ver. 5: user manual/tutorial. PRIMER-E, Plymouth.

Conroy-Dalton, S. - 2004. Systematics and phylogeny of the Ancorabolidae (Copepoda: Harpacticoida) V. Description of Lobopleura, new genus, with notes on Probosciphontodes Fiers. J. Crustac. Biol., 24: 17-36.

Corgosinho, P.H. and H. Gheerardyn. - 2009. A new species of Parameiropsis Becker, 1974 (Copepoda: Harpacticoida) from the Porcupine Seabight (NE Atlantic). Mar. Biodiv., doi: 10.1007/s12526-009-0005-8.

Coull, B.C. - 1973. Meiobenthic Harpacticoida (Crustacea, Copepoda) from the deep sea off North Carolina III. The families Tisbidae Stebbing emend. Lang, Thalestridae Sars emend. Lang, and Diosaccidae Sars. Trans. Am. Microsc. Soc. 92: 592-603.

De Mol, B., P. Van Rensbergen, S. Pillen, K. Van Herreweghe, D. Van Rooij, A. McDonnell, V. Huvenne, M. Ivanov, R. Swennen and J.P. Henriet. - 2002. Large deep-water coral banks in the Porcupine Basin, southwest of Ireland. Mar. Geol., 188: 193-231.

De Mol, B., J.P. Henriet and M. Canals. - 2005. Development of coral banks in Porcupine Seabight: Do they have Mediterranean ancestors? In: A. Freiwald and J.M. Roberts (eds.), Cold-water corals and ecosystems, pp. 515-533. Springer, Heidelberg.

Drzycimski, I. - 1968. Neue Harpacticoida (Copepoda) aus dem westnorwegischen Küstengebiet. Sarsia, 31: 15-23.

Drzycimski, I. - 1969. Harpacticoida (Copepoda) wod morskich okolic Bergen (zachodnie wybrzese norwegii) i ich ekologia. Rozpr. Wyzs. Szkola Rolnic. Szczecinie, 17: 1-72.

Fiers, F. - 1988. Taxonomie, Fylogenie en Zoogeografie van de Laophontidae (Copepoda, Harpacticoida). Ph.D. thesis, Ghent Univ.

Fiers, F. - 1991. Three new harpacticoid copepods from the Santa Maria Basin off the Californian Pacific coast (Copepoda, Harpacticoida). Beaufortia, 42: 13-47.

Fosså, J.H., P.B. Mortensen and D.M. Furevik. - 2002. The deepwater coral Lophelia pertusa in Norwegian waters: distribution and fishery impacts. Hydrobiologia, 471: 1-12.

Freiwald, A. - 2002. Reef-forming cold-water corals. In: G. Wefer, D. Billett, D. Hebbeln, B.B. Jorgensen, M. Schlüter and T. Van
Weering (eds.), Ocean Margin Systems, pp. 365-385. Springer, Berlin Heidelberg.

George, K.H. - 1999. Community analysis of the harpacticoid fauna of the Magellan Region, as well as first comparisons with Antarctic associations, basing on similarity analyses. Ber. Polarforsch., 327: 1-187.

George, K.H. - 2004. Description of two new species of Bodinia, a new genus incertae sedis in Argestidae Por, 1986 (Copepoda, Harpacticoida), with reflections on argestid colonization of the Great Meteor Seamount plateau. Org. Divers. Evol., 4: 241-264.

George, K.H. and H.K. Schminke. - 2002. Harpacticoida (Crustacea, Copepoda) of the Great Meteor Seamount, with first conclusions as to the origin of the plateau fauna. Mar. Biol., 144: 887-895.

Gheerardyn, H. and K.H. George. - in press. New representatives of the genus Ancorabolina George, 2006 (Harpacticoida, Ancorabolidae) including remarks on ancorabolid phylogeny. Zool. J. Linn. Soc.

Gheerardyn, H., S. Seifried and A. Vanreusel. - 2008a. A new species of Halophytophilus Brian, 1919 (Copepoda: Harpacticoida: Ectinosomatidae) from cold-water corals in the Porcupine Seabight (NE Atlantic). Zootaxa, 1761: 1-16.

Gheerardyn, H., M. De Troch, S.G.M. Ndaro, M. Raes, M. Vincx and A. Vanreusel. - 2008b. Community structure and microhabitat preferences of harpacticoid copepods in a tropical reef lagoon (Zanzibar, Tanzania). J. Mar. Biol. Assoc. U.K., 88(4): 747-758.

Gollner, S., V.N. Ivanenko and P. Martínez Arbizu. - 2008. A new species of deep-sea Tegastidae (Crustacea: Copepoda: Harpacticoida) from $9^{\circ} 50 ` \mathrm{~N}$ on the East Pacific Rise, with remarks on its ecology. Zootaxa, 1866: 323-326.

Hamond, R. - 1971. The Australian species of Mesochra (Crustacea: Harpacticoida) with a comprehensive key to the genus. Austral. J. Zool., suppl. 7: 1-32.

Heip, C., M. Vincx and G. Vranken. - 1985. The ecology of marine nematodes. Oceanogr. Mar. Biol. Annu. Rev., 23: 399-489.

Henry, L.-A. and J.M. Roberts. - 2007. Biodiversity and ecological composition of macrobenthos on cold-water coral mounds and adjacent off-mound habitat in the bathyal Porcupine Seabight, NE Atlantic. Deep-Sea Res. Part I, 54: 654-672.

Hicks, G.R.F. and B.C. Coull. - 1983. The ecology of marine meiobenthic harpacticoid copepods. Oceanogr. Mar. Biol. Annu. Rev., 21: 67-175.

Hicks, G.R.F. and G. Schriever. - 1985. Klieosoma nom. nov., a replacement name for Kliella Hicks and Schriever, 1983 (Copepoda, Harpacticoida, Ectinosomatidae). Crustac. Int. J. Crustac. Res., 49: 100-101.

Hurlbert, S.H. - 1971. The nonconcept of species diversity: a critique and alternative parameters. Ecology, 52: 577-586.

Huys, R., J.M. Gee, C.G. Moore and R. Hamond. - 1996. Marine and brackish water harpacticoid copepods. Part 1. In: R.S.K. Barnes and J.H. Crothers (eds.), Synopses of the British Fauna (New Series), 51: 1-352.

Jensen, A. and R. Frederiksen. - 1992. The fauna associated with the bank-forming deepwater coral Lophelia pertusa (scleractinaria) on the Faroe shelf. Sarsia, 77: 53-69.

Klie, W. - 1949. Harpacticoida (Cop.) aus dem Bereich von Helgoland und der Kieler Bucht. I. Kieler Meeresforsch., $6: 90-128$.

Knowlton, N. - 2001. The future of coral reefs. Proc. Natl. Acad. Sci. USA, 98: 5419-5425.

Kunz, H. - 1975. Harpacticoiden (Crustacea, Copepoda) aus dem Küstengrundwasser der französischen Mittelmeerküste. Zool. Scr., 3: 257-282.

Lambshead, P.J.D., H.M. Platt and K.M. Shaw. - 1983. The detection of differences among assemblages of marine benthic species based on an assessment of dominance and diversity. J. Nat. Hist., 17: 859-874.

Lang, K. - 1948. Monographie der Harpacticiden, I and II. Håkan Ohlssons Boktryckeri, Lund, Sweden.

Lang, K. - 1965. Copepoda Harpacticoidea from the Californian Pacific coast. Kungl. Svensk. Vetensk. Acad. Handl., (4) $10(2): 1-566$

Marinov, T. - 1971. Harpacticoids of the Bulgarian Black Sea coast. Proc. Inst. Oceanogr. Fish. Varna, 11: 43-87.

Martínez Arbizu, P. and G. Moura. - 1998. Atergopediidae, a new family of harpacticoid copepods (Crustacea) from oligothrophic 
Arctic sediments. Zool. Beitr., 38: 189-210.

Mielke, W. - 1974. Eulitorale Harpacticoidea (Copepoda) von Spitzbergen. Mikrofauna Meeresbodens, 37: 1-52.

Mielke, W. - 1979. Interstitielle Fauna von Galapagos. XXV. Longipediidae, Canuellidae, Ectinosomatidae (Harpacticoida). Mikrofauna Meeresbodens, 77: 1-107.

Noodt, W. - 1958. Die Copepoda Harpacticoidea des Brandungsstrandes von Teneriffa (Kanarische Inseln). Akad. Wiss. Lit. Mainz Abh. Math. Natur. Kl, 2: 51-116.

Noodt, W. - 1971. Ecology of the Copepoda. Smithson. Contrib. Zool., 76: 97-102.

Pallares, R.E. - 1970. Copepodos marinos de la ria Deseado (Santa Cruz, Argentina). Contribuçion sistematico-ecologica. III. Physis, 30(80): 255-282.

Pesta, O. - 1959. Harpacticoiden (Crust. Copepoda) aus submarinen Hohlen une den benachbarten Litoralbezirken am Kap von Sorrent (Neapel). Publ. Staz. Zool. Napoli, 30(suppl.): 95-177.

Por, F.D. - 1960. Littorale Harpacticoiden der Nordwest-Kusten des Schwarzen Meeres. Trav. Mus. Hist. Nat. "Gr. Antipa", 2: 97-143.

Raes, M. and A. Vanreusel. - 2005. The metazoan meiofauna associated with a coldwater coral degradation zone in the Porcupine Seabight (NE Atlantic). In: A. Freiwald and J.M. Roberts (eds.), Cold-water corals and ecosystems, pp. 821-847. Springer, Heidelberg.

Raes, M. and A. Vanreusel. - 2006. Microhabitat type determines the composition of nematode communities associated with sediment-clogged cold-water coral framework in the Porcupine Seabight (NE Atlantic). Deep-Sea Res. Part I, 53: 1880-1894.

Raes, M., W. Decraemer and A. Vanreusel. - 2008. Walking with worms: coral-associated epifaunal nematodes. J. Biogeogr., 35: 2207-2222.

Raes, M., W. Decraemer and A. Vanreusel. - 2009. Draconematidae (Nematoda) from cold-water corals in the Porcupine Seabight: The genus Tenuidraconema Decraemer, 1989. Org. Divers. Evol., 9: 41.e1-41.e21.

Rogers, A.D. - 1999. The biology of Lophelia pertusa (Linnaeus 1785) and other deep-water reef-forming corals and impacts from human activities. Int. Rev. Hydrobiol., 84: 315-406.

Rose, A., S. Seifried, E. Willen, K.H. George, G. Veit-Köhler, K. Bröhldick, J. Drewes, G. Moura, P. Martínez Arbizu and H.K. Schminke. - 2005. A method for comparing within-core alpha diversity values from repeated multicorer samplings, shown for abyssal Harpacticoida (Crustacea: Copepoda) from the Angola Basin. Org. Divers. Evol., 5: 3-17.

Sanders, H.L. - 1968. Marine benthic diversity: a comparative study Am Nat., 102: 243-282.

Sars, G.O. - 1908. Copepoda Harpacticoida. Parts XXIII and XXIV. Laophontidae (continued). An Account of the Crustacea of Norway, with short descriptions and figures of all the species. 5: $257-276$

Sars, G.O. - 1920. Copepoda Supplement. Parts III and IV. Harpacticoida (continued). An Account of the Crustacea of Norway, with short descriptions and figures of all the species. 7: 25-52.

Seifried, S. - 2003. Phylogeny of Harpacticoida (Copepoda): Revision of "Maxillipedasphalea" and Exanechentra. Cuvillier, Göttingen.

Seifried, S. - 2004. The importance of a phylogenetic system for the study of deep-sea harpacticoid diversity. Zool. Stud., 43: 435-445.

Shimanaga, M., H. Kitazato and Y. Shirayama. - 2004. Temporal patterns in diversity and species composition of deep-sea benthic copepods in bathyal Sagami Bay, central Japan. Mar. Biol., 144: $1097-1110$.

Soyer, J. - 1964a. Copépodes Harpacticoïdes de l'étage bathyal de la région de Banyuls-sur- Mer: III. Le genre Fultonia T. Scott, genre nouveau pour la Méditerranée. Vie Milieu, 15(1): 95-103.

Soyer, J. - 1964b. Copépodes Harpacticoïdes de l'étage bathyal de la région de Banyuls-sur- Mer: V. Cletodidae T. Scott. Vie Milieu, 15(3): 573-643.

Soyer, J. - 1966. Copépodes Harpacticoïdes de Banyuls-sur-Mer: 3. Quelques formes du coralligène. Vie Milieu, 17(1-B): 303-344.

Soyer, J. - 1974. Contribution à l'étude des Copépodes Harpacticoïdes de Méditerranée occidentale. 8. Le genre Pseudobradya Sars. Systématique, écologie. Vie Milieu, 24(1-A): 127-154.

Thistle, D. - 1978. Harpacticoid dispersion patterns: implications for deep-sea diversity maintenance. J. Mar. Res., 36: 377-397.

Vincx, M., B.J. Bett, A. Dinet, T. Ferrero, A.J. Gooday, P.J.D. Lambshead, O. Pfannkuche, T. Soltwedel and A. Vanreusel. - 1994. Meiobenthos of the deep Northeast Atlantic. Adv. Mar. Biol., 30: 1-88.

Willen, E. - 2000. Phylogeny of the Thalestridimorpha Lang, 1944 (Crustacea, Copepoda). Cuvillier, Göttingen.

Willen, E. - 2002. Notes on the systematic position of the Stenheliinae (Copepoda, Harpacticoida) within the Thalestridimorpha and description of two new species from Motupore Island, Papua New Guinea. Cah. Biol. Mar., 43: 27-42.

Scient. ed.: M.P. Olivar.

Received September 15, 2008. Accepted March 24, 2009.

Published online August 6, 2009. 